\title{
A prática de revisão de textos entre inadequação e inovação: uma discussão sobre variação, mudança e política linguística
}

\author{
Carolina P. Fedatto* \\ Beatriz Garcia Pinto Coelho**
}

\begin{abstract}
Resumo
O artigo procura problematizar as noções de uso, variação e mudança linguística na prática de revisão de textos por meio da discussão de vocábulos polêmicos entre gramáticos tradicionais e linguistas. Empregos como o do demonstrativo "mesmo" substantivado como anafórico e "onde" com sentido não espacial são condenados por concepções mais puristas da língua, pois não estariam de acordo com um sentido original defendido por alguns gramáticos. No entanto, estudos linguísticos baseados na descrição do uso desses vocábulos em textos da norma padrão demonstram que essas novas acepções estão em plena produtividade na língua, sendo entendidas como gramaticalizadas no português padrão. Entre essas duas posições, os profissionais do texto são chamados, em sua prática, a decidir sobre a correção ou não de formas consideradas, por um lado, como inadequadas e por outro, como inovadoras. Nosso objetivo é contribuir para uma decisão refletida por parte desses profissionais, colocando em pauta o papel da revisão de textos nas discussões sobre políticas linguísticas.

Palavras-chave: Revisão de textos. Inadequações vocabulares. Variação e mudança linguística. Gramática do uso;. Políticas linguísticas.
\end{abstract}

A língua é como é, não como deveria ser. (Mário Perini, Sofrendo a gramática)

\section{Introdução}

As discussões em torno da adequação das formas linguísticas aos diversos contextos de uso estão muito presentes nos estudos da linguagem. Desde as

* Professora de Ciências da Linguagem na Universidade do Vale do Sapucaí e Pesquisadora de pósdoutorado na UFF e UFMG; carolinafedatto@yahoo.com.br

** Professora da Aliança Francesa de Belo Horizonte e Especialista em Revisão de Textos pela Pontifícia Universidade Católica de Minas Gerais; biagpc@yahoo.com.br 
concepções mais tradicionais, que buscam explicitar um sentido verdadeiro e um contexto ideal para as formas da língua, até as visões da linguística descritiva em seu viés histórico, funcionalista ou variacionista, a tensão entre adequação e inovação fundamenta o entendimento dos sentidos e das funções dos elementos linguísticos. A emergência da teoria da comunicação e dos estudos sobre língua e sociedade contribuíram para o entendimento de que há fatores extralinguísticos atuando na estabilização do sistema linguístico. Embora não haja ligação direta entre o sistema da língua (seja no nível fonológico, morfológico ou sintático) e seu funcionamento político e histórico, não se pode negar a influência da exterioridade na construção dos critérios que diferenciam línguas e dialetos, padrões e variantes, mudança e variação. Émile Benveniste (1968/1989, p.94) mostra que linguagem e sociedade se implicam mutuamente, mesmo não havendo analogia entre suas estruturas. Além disso, o desenvolvimento histórico dessas duas entidades também se dá separadamente: nada condiciona uma mudança de estrutura linguística quando há grandes transformações sociais, nem as mudanças sociais implicam alterações na base da língua.

O linguista afirma ainda que, apesar de não podermos estabelecer uma correlação necessária entre uma língua histórica e uma sociedade histórica, há homologias no nível conceitual. Em termos teóricos, língua e sociedade são consideradas, na linguística e na sociologia, realidades inconscientes que representam o mundo, as ideias, o pensamento. Elas são também sempre herdadas sem que se possa imaginar existir um começo e, finalmente, vemos que nenhuma delas pode ser mudada pela simples vontade dos homens. O que os homens veem e podem mudar por meio da história são as instituições, mas não o princípio da sociedade que é suporte e condição da vida coletiva e individual. Da mesma maneira, o que muda na língua, o que os homens podem mudar, são as designações, que se multiplicam, se substituem e são sempre conscientes, mas jamais o sistema fundamental da língua (BENVENISTE, 1989, p. 96). Dessa analogia conceitual entre língua e sociedade pode-se supor, por outro lado, certa autonomia da língua, que acolhe e nomeia as condições da existência e as transformações da vida social, mas essas mudanças não afetam diretamente sua estrutura. A língua muda apenas sob a pressão de necessidades internas de forma que os falantes não testemunham a mudança linguística.

Se não há língua fora da sociedade e se a sociedade não tem o poder de transformar, voluntária ou legalmente, a estrutura da língua, como podemos 
compreender as influências mútuas entre essas duas instâncias? Esse tipo de questão nos leva a refletir sobre a necessidade de gerenciar as diferenças entre as línguas e também as desigualdades no interior de um mesmo idioma. As noções de política linguística e sua colocação em prática, a planificação linguística, surgem no contexto de nascimento da sociolinguística norte-americana dos anos de 1960. Embora a intervenção humana sobre as línguas seja mais antiga, é a partir dessa época que há um florescimento de publicações científicas consagradas aos problemas linguísticos dos países colonizados e das minorias linguísticas. Esses estudos sobre as desigualdades nas línguas colocarão numerosas questões (e soluções) sobre as funções sociais da língua e sobre as funções linguísticas da sociedade, inaugurando um campo de pesquisas que traz para o centro das preocupações o caráter político das relações entre as línguas e os estratos das línguas. Formulam-se, então, conceitos como o de diglossia - coexistência conflituosa entre línguas dominadas e línguas dominantes - e tipologias das situações plurilíngues que estabelecem nomenclaturas e classificações ainda hoje vigentes, como: língua padrão, clássica, artificial, vernacular, dialeto, crioulo e pidgin, além de qualificativos sobre as funções das línguas, tais quais: materna, nacional, oficial, franca, veicular.

É o linguista Louis-Jean Calvet quem retoma essa trajetória de emergência da noção de política linguística ligada aos estudos sociolinguísticos e discute suas implicações teóricas. A história recente de intervenção voluntária no estatuto das línguas mostra que as políticas linguísticas costumam colocar em cena a sua linguística, isto é, uma determinada visão científica sobre as línguas (CALVET, 1996, p. 123). Numa época em que a ciência apenas descrevia a estrutura das línguas, os teóricos das políticas linguísticas também só se preocupavam com a ação sobre a forma das línguas. Depois, à medida que a linguística se torna sociolinguística, as políticas passam a se interessar pelas funções das línguas. Não se pode escapar, então, de uma reflexão sobre a sustentação teórica da possibilidade de que haja políticas linguísticas.

Tendo essa inquietação ao fundo, este estudo busca contribuir para as discussões sobre adequação e inovação vocabular no contexto das práticas de revisão de textos, colocando como questão teórica central o problema da aceitação social das mudanças linguísticas e o papel político dos profissionais do texto nesse processo. Para tanto, a primeira parte do artigo apresenta questões teóricas sobre a função social dos revisores de texto acompanhada de um apanhado conceitual 
sobre o problema da variação e da mudança linguística. A seguir, na segunda parte, serão analisados estudos cotejando o viés da gramática tradicional com os estudos linguísticos de expressões com empregos polêmicos, como "o mesmo" em função anafórica e "onde" com sentido não espacial. Nas reflexões finais, buscaremos tirar as conclusões políticas do caráter desigual atribuído às formas e sentidos das expressões estudadas, atentando para o papel dos profissionais do texto na disseminação e consolidação de formas inovadoras ou conservadoras e suas imagens sociais de correção e adequação.

\section{Apontamentos teóricos}

\subsection{A tarefa do revisor de textos}

O ofício da revisão de textos contempla o imaginário de que, por melhor que uma pessoa escreva, a leitura do seu texto por outrem contribui, na maioria das vezes, para o aperfeiçoamento da expressão das ideias que se quer transmitir. Às vezes essa leitura é amadora, feita por pais, amigos ou colegas de trabalho. Contudo, dependendo do valor afetivo que o autor atribui ao texto ou da sua importância social, como no caso de livros destinados à publicação, textos acadêmicos, propagandas publicitárias (e políticas), entre outros, recorre-se, para tal tarefa, a profissionais do texto. A tendência atual é que uma única pessoa acumule todas as funções relativas às diferentes etapas da edição de textos, sobretudo fora do mercado editorial formal (YAMAZAKI, 2007). Geralmente, esse profissional é o preparador ou o revisor de textos, em especial nas publicações independentes. Destarte, ele tem o papel de fazer a normatização, a padronização segundo a ABNT (quando for o caso), a revisão ortográfica e gramatical, a revisão de estilo, o que corresponde, com frequência, à adaptação e mesmo à redação de alguns trechos do original. Seu trabalho é zelar pelo uso coerente de "[...] pontuação, acentuação, maiúsculas, minúsculas e outros realces gráficos (grifos, negritos etc.), citações, abreviaturas, bibliografia" (MARTINS FILHO; ROLLEMBERG, 2001, p.85) e alterar ocasionais erros de digitação, hifenização, cacofonias, uso incorreto de tempos verbais. A fim de cumprir esse papel, o profissional precisa realizar várias leituras, até que o texto atenda os padrões esperados para cada tipo de obra e que possíveis falhas que prejudiquem sua compreensão pelo leitor sejam eliminadas tanto quanto possível. 
Enfim, segundo os responsáveis pela Editora da USP (Edusp), "sua tarefa principal [a do revisor] é facilitar a vida do leitor, dando unidade e clareza não só às ideias, mas ao livro [ou texto] como um todo, dando-lhe, enfim, consistência" (MARTINS FILHO; ROLLEMBERG, 2001, p.87). Na mesma obra, intitulada Edusp, um projeto editorial, os autores, com muita criatividade, indicam algumas regras que devem guiar a atividade do revisor "como um mantra", a saber: "ter atenção cirúrgica, paciência bíblica, humildade franciscana e nunca, em tempo algum, corrigir por capricho - apenas por necessidade" (p.88).

A ideia de "facilitar a vida do leitor" exposta acima parece nos conduzir à teoria da comunicação. A legibilidade (ou compreensibilidade) deve ser garantida pelo profissional do texto; ela está na essência do seu trabalho. O revisor é um intermediário entre o emissor (autor) e o receptor (leitor) da mensagem. Não deve modificá-la, porém tem o papel de diminuir as chances de que ela seja compreendida equivocadamente, de que, por causa de um eventual emprego inadequado do código, não chegue ao receptor. De acordo com Cristina Yamazaki,

o editor [mas também o revisor] é de início o receptor da mensagem original; não o receptor visado pelo texto, mas um membro da audiência. E, depois de trabalhar no texto, se torna [ao lado do autor] o emissor da mensagem. Esse profissional age como um facilitador na tensão entre o significado intencional e o significado recebido e tem que reduzir essa tensão ao máximo para que o significado possa ser transmitido da forma mais eficaz possível. Portanto, pode-se dizer que o editor busca criar condições mais favoráveis para o esquema comunicativo. Sem a interferência do editor de texto, a compreensão da mensagem pode ficar comprometida. (YAMAZAKI, 2007, p.18-9).

Entretanto, as intervenções dos profissionais de texto não devem mudar o estilo do autor, até porque o estilo pressupõe características individuais, mas têm a função de garantir a legibilidade e aceitação de um texto diante de determinado público (YAMAZAKI, 2008). A comunicóloga defende que, no processo da edição, a obsessão pela correção dos erros seja substituída por uma obsessão pela legibilidade.

De todo modo, as escolhas relativas à adequação de certos usos à norma padrão nem sempre se mostram fáceis para os revisores de textos. A discórdia entre gramáticos conservadores e linguistas adeptos ao uso dificulta ainda mais a tomada de decisão pelo profissional do texto. A não intervenção em dado uso 
pode ser interpretada como desleixo ou até mesmo mera ignorância do revisor e, como consequência, também do autor. Dessa forma, revisores muitas vezes se questionam sobre seu trabalho e atendem, sem refletir sobre seu papel nas políticas linguísticas, a essa demanda normativista. Considerando, no entanto, que, do ponto de vista da comunicação, o objetivo maior da revisão seria tornar o texto claro e acessível ao público-alvo, como encaminhar as intervenções nos textos? O revisor deve simplesmente adaptá-los a uma língua idealizada, que segue as regras prescritas pelas gramáticas normativas, pelos dicionários diversos, pelos manuais de redação e estilo - entre eles, os do mundo da mídia? Ou ele pode adotar uma postura condizente com os estudos da língua em uso, as discussões das gramáticas e dicionários centrados nas práticas comunicativas que não desconsideram os falantes nem as relações sociais? Para que essa opção seja possível aos profissionais do texto, sejam eles autores, revisores ou editores, é preciso que se discutam publicamente e com rigor as diversas perspectivas teóricas e descritivas que sustentam a constatação e aceitação de novos usos da língua.

Uma das melhores obras destinadas à redação - e talvez a mais editada - foi publicada pela primeira vez em 1967, contando atualmente com quase trinta edições, o que demonstra, no mínimo, seu grande valor para aqueles que buscam escrever bem. Trata-se do livro "Comunicação em prosa moderna", escrito por Othon Garcia. Nas suas páginas iniciais, entendemos a razão do sucesso. Na seção "Explicação necessária", o autor deixa claro que, diferentemente de alguns manuais do gênero disponíveis no mercado, sua obra não se limita à gramática normativa e à estilística, priorizando o conteúdo em detrimento da forma, nos seus termos a "carga semântica" em oposição ao "polimento da frase". Citamos abaixo uma passagem que ancora a convicção de que a função do revisor tem diretamente a ver com o modo como o texto circula, comunica e afeta o leitor:

Estamos convencidos [...] de que correção gramatical não é tudo mesmo porque, no tempo e no espaço, seu conceito é muito relativo - e de que a elegância oca, a afetação retórica, a exuberância léxica, o fraseado bonito [...] com mais frequência falseiam a expressão das ideias do que contribuem para a sua fidedignidade. É principalmente por isso que $[. .$.$] insistimos em considerar como virtudes primordiais$ da frase a clareza e a precisão de ideias [...], a coerência [...], e a ênfase [...] (GARCIA, 2010, p.6, grifo nosso). 
Além da primazia das ideias sobre a forma, ele evidencia a necessária distinção entre simples purismo gramatical e correção. Os profissionais do texto são chamados a ocupar uma posição na querela entre tradição e inovação e, por isso, seria interessante discutirmos como pode se dar o processo de variação e mudança linguística de algumas expressões bastante controversas, usadas mas condenadas. Entendemos que, na prática de revisão de textos, deve-se restringir o alcance dos purismos e privilegiar a compreensão do funcionamento comunicativo dos textos. Precisamos, para isso, conhecer o repertório dos variados usos linguísticos atuais, visando ajustar os textos aos seus leitores.

Em meio a purismos de toda sorte, encontramos nas obras de referência inúmeras recomendações sobre o uso de determinados vocábulos. Muitas vezes, trata-se de termos da língua que passaram a ser utilizados com sentido diferente do aceito e descrito originalmente, o que, numa perspectiva normativa e conservadora, configura as famosas inadequações vocabulares. Contudo, do ponto de vista dos estudos linguísticos, sobretudo em relação aos processos de variação e mudança linguística, essas modificações de sentido não seriam erros, mas sim novos usos legítimos, uma vez que resultantes do inevitável processo de mudança das línguas. É considerando essa realidade dos sistemas linguísticos que colocamos em discussão a interpretação de alguns usos da língua a partir de diferentes pontos de vista. Primeiramente, consideraremos os estudos que buscam compreender descritivamente os processos de variação e mudança para, na seção seguinte, realizar um inventário analítico dos trabalhos que tomam determinados usos sob o enfoque da inadequação.

\subsection{Sobre variação e mudança linguística}

A compreensão da relação entre variação e mudança linguística é um produto do sucesso dos estudos comparatistas empreendidos a partir de meados do século XIX. Esses estudos se baseiam na descrição e comparação de diferentes línguas em diversos momentos históricos dando origem ao que se conhece como a ciência linguística moderna. Quando se comparam textos antigos com outros mais contemporâneos, percebe-se que, embora sejam escritos na mesma língua, há diferenças significativas. Tais diferenças provam que as línguas humanas mudam com o passar do tempo. Faraco, na sua obra introdutória à Linguística Histórica, explica que elas não constituem realidades estáticas, alterando-se continuamente (FARACO, 2005, p.14). 
Em seu clássico "Linguística Românica", Heinrich Lausberg desenvolve uma argumentação certeira para justificar o fenômeno da mudança linguística ao associá-lo à evolução da humanidade. Em suas palavras, "as mudanças linguísticas não têm nada de estranho, mas representam no campo linguístico a correspondência análoga das mudanças históricas em geral, que são próprias da humanidade imersa no decurso temporal da história: a imutabilidade seria algo desumano e, portanto, altamente estranho" (LAUSBERG, 1981, p.43). Segundo o filólogo alemão, "a língua é um sistema de equilíbrio", que oscila entre sistema e caos (LAUSBERG, 1981, p.44). O linguista brasileiro diz o mesmo, porém com outras palavras: a língua seria um "complexo jogo entre mutação e permanência" (FARACO, 2005, p.15).

Diz-se, em Linguística Histórica, que toda mudança pressupõe variação, mas nem toda variação implica mudança. Significa afirmar igualmente que a mudança só é possível porque a língua é uma realidade heterogênea (FARACO, 2005, p. 23-4). O caminho para a implementação da mudança é longo: primeiro, a variação se dá na fala informal, depois, na fala formal, para só depois ocorrer na escrita (FARACO, 2005, p.26). Isso acontece por causa do conservadorismo típico da língua escrita. O exercício do controle social bloqueia a entrada das formas inovadoras. Esse exercício vem dos estudiosos da língua, bem como dos falantes dos grupos socioeconômicos mais altos, que reagem negativamente às inovações, considerando-as parte de um processo de degradação ou corrupção (FARACO, 2005, p.25-7). "É com a quebra progressiva desse estigma (isto é, com a mudança de valores correlacionada com mudanças nas relações sociais) que as formas inovadoras vão adquirindo condições de se expandir para outras variedades da língua" (FARACO, 2005, p.28). A esse respeito, Lausberg nos esclarece que a instabilidade dos sistemas linguísticos é um processo regulado pela dialética "liberdade/norma". Ele explica que a "norma mínima" garante a inteligibilidade na comunicação. Toda e qualquer norma que transpasse a mínima é do campo comunitário ou individual, com razões tais quais conveniência social, busca pela estética, originalidade etc. (LAUSBERG, 1981, p.45).

Em 1963, o norte-americano William Labov funda a chamada Teoria da Variação, com um estudo sobre a variação na pronúncia dos habitantes da ilha turística de Martha's Vineyard (Massachusetts, EUA). A importância dessa teoria é a inclusão das componentes sociais (opondo-se ao Gerativismo de Chomsky) na afirmação do caráter não aleatório da variação, através da fundamentação empírica 
com base no tratamento estatístico de dados coletados. Junto com outros dois linguistas, Weinreich e Herzog, em 1968, sistematiza um conjunto de princípios gerais para o estudo da mudança linguística baseado na heterogeneidade ordenada das línguas, no qual a motivação social seja considerada (WEINREICH; LABOV; HERZOG, 2006). A variação linguística vem, portanto, da heterogeneidade da sociedade. Seus membros têm à sua disposição um grande leque de formas linguísticas. Normalmente as escolhas não ocorrem de forma individualizada, mas sim coletiva. Obviamente, quanto maior a influência da norma linguística socialmente estabelecida (codificação e prescrição pela gramática normativa), menor será o grau do fenômeno da variação (LIMA, 2007).

A Linguística Funcionalista desenvolveu, no início da década de 1980, a teoria da gramaticalização. Na verdade, trata-se de um ressurgimento do interesse pela questão, que, já em 1912, havia sido discutida por Antoine Meillet. Inicialmente o termo se referia a um tipo especial de mudança linguística, na qual unidades ou construções de base lexical, em certos contextos linguísticos, passam a servir a funções gramaticais. Quando isso ocorre, essas unidades ou construções tendem a ter um uso mais regular e restrito, o que caracteriza os termos gramaticais em geral (GONÇALVES; LIMA-HERNANDES; CASSEB-GALVÃO, 2007). No sentido mais abrangente do termo, atualmente falamos de gramaticalização também quando palavras ou expressões discursivas ou gramaticais assumem um caráter ainda mais gramatical. Ou seja, mesmo mudanças semânticas podem ser casos de gramaticalização.

Dessa maneira, mesclando ideias das diferentes subdisciplinas da Linguística discutidas acima (histórica, variacionista e funcionalista), podemos dizer que alguns termos da língua começam a ser utilizados com sentido diferente do normatizado, configurando uma variação da língua, que, por vezes, resulta em mudança linguística. Essa mudança linguística constitui, em alguns casos, um processo de gramaticalização. O uso da expressão "através de" como sinônimo de "por meio de" e o uso de "onde" com acepção de localização textual (e mesmo temporal) são exemplos de casos de gramaticalização.

Se essas inovações estão totalmente disseminadas na língua escrita padrão, os revisores poderiam considerá-las então mudanças concluídas e assim não intervir nesses usos? Como saber quando devemos aceitar um uso disseminado na língua? Em que momento ele passa a fazer parte da norma padrão? O profissional do texto deve se guiar somente pela gramática normativa, atuando na contramão da mudança 
linguística? É a essas perguntas que almejamos responder neste artigo. Passemos, desse modo, à análise de alguns desses termos cujos usos são tema de discussões acirradas entre os estudiosos da língua portuguesa. Estudaremos a seguir algumas perspectivas de descrição de dois vocábulos: "mesmo" empregado anaforicamente e "onde" com sentido não espacial. Essas análises podem ser estendidas a outros termos em discussão nas polêmicas entre puristas e linguistas, como o advérbio "inclusive" com sentido de "até mesmo", "através de" como sinônimo de "por meio de", "enquanto" como conjunção conformativa, a expressão "a partir de" em acepções não temporais, entre outros sentidos que o uso cria, transforma e renova.

\section{Apontamentos analíticos}

\subsection{0 emprego anafórico do demonstrativo "mesmo" substantivado por artigo}

Em textos de circulação geral, bem como naqueles restritos ao meio acadêmico, deparamo-nos frequentemente com o uso anafórico de "o mesmo" (e suas variantes em gênero e número), ou seja, com tal expressão fazendo referência a coisas ou pessoas já mencionadas anteriormente. Evanildo Bechara apresenta o exemplo a seguir, citando uma frase do célebre romance machadiano Dom Casmurro: "Costuma-se escrever dentro dos livros, na folha de guarda, palavras alusivas aos mesmos." (MACHADO DE ASSIS apud BECHARA, 2003, p.168).

No Dicionário Houaiss da língua portuguesa, o verbete da palavra "mesmo" traz treze acepções, divididas em quatro classes gramaticais, na seguinte ordem: adjetivo, pronome, substantivo e advérbio. Uma dessas acepções é de uso controverso entre estudiosos da língua: a oitava (na qual o vocábulo apresenta natureza pronominal), que apenas diz: "com função substantiva (e valor demonstrativo)" e mais especificamente a 8.1, aqui transcrita "o indivíduo; a pessoa; ele, aquele" (HOUAISS, 2007, p.1.903). Dois exemplos se seguem. O segundo não consiste, de modo algum, em uma anáfora e, infelizmente, através do primeiro exemplo, também não conseguimos ter certeza de que os lexicógrafos quiseram incluir uma anáfora. Vejamos a frase: "foi sempre o mesmo na defesa das minorias". Podemos determinar se foi sempre o mesmo indivíduo, com suas características essenciais ou se foi sempre ele, alguém referido anteriormente? Fora do contexto, é impossível saber se incluíram, de fato, o emprego anafórico de "o mesmo". 
É bem verdade que, etimologicamente falando, o vocábulo é atestado no séc. XIII (e no séc. XII com a grafia meesmo) como adjetivo pronominal, conforme o "Dicionário etimológico da língua portuguesa" de Antônio da Cunha, o que não significa, contudo, que a palavra não possa, ao longo dos séculos, começar a ser empregada de forma distinta.

Um dos gramáticos mais irônicos e conservadores da nossa língua, Napoleão Mendes de Almeida, reserva quase uma página de letras miúdas para o termo em seu "Dicionário de questões vernáculas". Ele começa asseverando: "Erro muito frequente é o emprego do demonstrativo mesmo com função pronominal [...]." (ALMEIDA, 2003, p.339). O filólogo apresenta como razão para tal "erro" a hipercorreção (ainda que não se valha desse conceito nos estudos linguísticos): "muitos, desconhecedores de nosso idioma, passaram a fugir do pronome ela, eliminando-o em toda circunstância, para substituí-lo por a mesma. Viciados com tal substituição, o mesmo fizeram com o masculino ele [...]”. E para finalizar, afirma categoricamente: "[...] a palavra mesmo, que tem muitas e muitas funções, não tem a de substituir o pronome ele" (ALMEIDA, 2003, p.340). Como provocação final, Napoleão incita os leitores a imaginarem Camões empregando o vocábulo "mesmo" erroneamente. Será que ele se esqueceu do quão longínqua está a época do grande poeta em relação ao século XX?

Enquanto o renomado defensor da língua portuguesa do século XVI desabona veementemente o emprego, Maria Helena de Moura Neves, pesquisadora dedicada aos estudos da língua em uso, no seu "Guia de usos do português", limitase a declarar: "é condenado em alguns manuais tradicionais o uso de o mesmo, a mesma, os mesmos, as mesmas para referência a alguma pessoa ou a alguma coisa já mencionada (valendo por ele, ela, eles, elas, respectivamente)" (NEVES, 2003, p.516-7). A autora oferece ao falante/escrevente, dessa maneira, a liberdade de escolha entre o conservadorismo e o efetivo uso da língua. Convém, todavia, lembrar que na "Gramática de usos do português", de sua autoria, ela não elenca esse uso de "mesmo" entre as possíveis funções do vocábulo, somente as de "reforçador de identidade" e de "indicador de identidade idêntica" (NEVES, 2000, p.492-3).

Uma posição intermediária entre Almeida e Neves aparece no "ABC da língua culta”, de Celso Luft, nome de referência nos estudos do português. Segundo ele, deve-se evitar o abuso da locução na remissão a um substantivo anterior. Vemos, assim, que o autor não se refere a erro, mas recusa o emprego excessivo de "o mesmo". Enxerga o abuso como "[...] imperícia, falta de recursos de linguagem, ou mau gosto estilístico" (LUFT, 2010, p.318). 
Cegalla, no seu "Dicionário de dificuldades da língua portuguesa", sugere igualmente evitar-se esse uso de mesmo, porém admite que existam alguns casos mais difíceis, nos quais não é possível substituir o termo pelo pronome pessoal ele. O gramático propõe como exemplo desses casos complicados a seguinte frase:

Esse cidadão, sem qualquer capacidade técnica nem conhecimento do local, vem propondo projetos absurdos para a utilização do parque Monte Azul, enquanto que nossa associação encomendou o estudo científico do mesmo a uma entidade de prestígio internacional (CEGALLA, 2009, p.255).

No "Manual de redação do Estadão", o uso aqui em discussão aparece como o $69^{\circ}$ erro mais comum da língua portuguesa (MARTINS, 1997, p.325). Segundo o manual citado, "é condenável o uso de o mesmo, a mesma, os mesmos, as mesmas para substituir pronome ou substantivo. Estão vetadas, dessa forma, construções [...] do gênero" (MARTINS, 1997, p.177). Em seguida, uma lista de exemplos reais é apresentada. Já o "Manual da redação da Folha", bem como o "Manual de redação da Presidência da República", não faz nenhuma menção a essa utilização de "o mesmo".

Finalmente, o conceituado gramático Evanildo Bechara adota uma postura crítica em relação aos opositores do emprego ora discutido - tal postura parecenos coerentemente compatível com o adjetivo moderna que dá nome à gramática por ele escrita. Certamente não poderíamos deixar de expor suas palavras bem medidas:

\footnotetext{
Alguns estudiosos, por mera escolha pessoal, têm-se insurgido contra o emprego anafórico do demonstrativo 'mesmo', substantivado pelo artigo, precedido ou não de preposição, para referir-se a palavra ou declaração expressa anteriormente. Não apresentam, entretanto, as razões da crítica (BECHARA, 2003, p.168).
}

Adotando a mesma postura crítica que Bechara, propomos uma reflexão: se o pronome demonstrativo "este" e suas variantes são utilizados ora com função substantiva, ora com função adjetiva, por que não poderia ser assim com "o mesmo"?

Esses diferentes modos de questionar a adequação do uso de "o mesmo" apontam para a impossibilidade de abolição de um viés normativo sobre a língua. Mesmo que estudos linguísticos de caráter descritivo mostrem a produtividade 
desse uso na língua culta, notamos que no discurso sobre a língua há inúmeras discussões que pautam uma política de normatização de usos considerados melhores do que outros.

\subsection{O emprego de "onde" com sentido não espacial}

Segundo o Dicionário Houaiss da língua portuguesa, a palavra "onde" é um advérbio que denota valor circunstancial, em frase interrogativa ou especializando situações estáticas. Contudo, em observações que se seguem, apesar de não a classificarem como pronome, os dicionaristas destacam sua função de subordinação entre termos e orações. Abordam igualmente seu papel anafórico e catafórico. No campo etimológico, despertam a atenção para a variação histórica entre "onde" e suas formas com a preposição incorporada (aonde, adonde, donde), que perdura até os dias de hoje. Vale salientar que, em nenhum momento, comentaram ou exemplificaram outros sentidos que não o locativo.

Se a equipe responsável pelo Dicionário Houaiss da língua portuguesa nem sequer menciona os demais sentidos que são recorrentes na escrita culta, o Novo Aurélio Século XXI registra o sentido temporal da palavra (sinônima de "quando, enquanto"), porém, curiosamente, como brasileirismo do Nordeste e provincialismo português, não apresentando exemplos. Ademais, inclui-se o termo "onde" na classe dos pronomes, além da dos advérbios.

Nas gramáticas normativas, assim como nas de uso, a palavra "onde" é classificada comumente como advérbio, mas algumas vezes também como pronome relativo. Os locativos latinos dos quais a palavra portuguesa deriva (dentre eles, ubi e unde) já apareciam com a função de conectivo relativo. Os grandes etimologistas Ernout e Meillet categorizaram o termo latino ubi como advérbio de lugar, relativo e interrogativo, correspondente a várias traduções em português, quais sejam: "no lugar onde", "onde" e, surpreendentemente, "no momento em que, quando, logo que", as últimas com inegável valor temporal (ERNOUT; MEILLET apud LIMA, 2007). Em português arcaico, ubi evolui para $h u$ - que equivale aos atuais "onde" e "para onde" -, coexistindo com a forma "onde" (derivada do latim unde), equivalente a "de onde" em português contemporâneo.

É bem verdade que, no português de nossos dias, não encontramos mais termos vindos do $h u$; entretanto, no francês atual, a palavra où apresenta valor 
locativo e, completamente legitimado pela gramática normativa, valor temporal. Já o vocábulo espanhol donde não funciona, de fato, para retomar um antecedente temporal, embora, tal qual ocorre com seu análogo português, vá além da propriedade locativa, agindo como operador discursivo de conclusão, finalidade e condição (LIMA, 2007).

A dissertação de mestrado de Sóstenes Cezar de Lima, "Impacto do vernáculo sobre o uso do onde na escrita monitorada", orientada por Marcos Bagno, mostra como variados usos de "onde" já se disseminaram nos textos das camadas teoricamente mais letradas do país (estudantes de Letras e professores de Português), mesmo aqueles condenados por gramáticos e especialistas da língua. Segundo o autor, oito valores semânticos de "onde" podem ser detectados inclusive na escrita monitorada, quais sejam: locativo concreto, locativo abstrato, possessivo, instrumental (estes quatro no grande campo semântico espaço), temporal, fórico textual, operador argumentativo e marcador discursivo (os três últimos no campo do texto). Contudo, dentre os oito, somente o uso de "onde" com valor locativo concreto é abonado pela tradição gramatical, o que já pôde ser visto nos dicionários acima analisados. Vejamos, a seguir, de que forma gramáticas, dicionários de dificuldades da língua e manuais de redação e estilo tratam a questão.

Cunha e Cintra discutem o contraste entre "onde" e "aonde", salientando que, embora haja uma justificativa gramatical forte, ele não é - e mesmo nos clássicos já não era - respeitado. Já Bechara faz alusão à distinção acima referida e acredita ser ela cada vez mais levada em consideração na língua escrita contemporânea. No que concerne aos usos de "onde" sem noção locativa, nem os primeiros nem o último se pronunciam. Luft, igualmente, não faz nenhuma menção aos outros sentidos.

No "Manual do Estado de S. Paulo", desaconselha-se outros usos de "onde". Os editores do jornal concorrente fazem o mesmo, insistindo: "Não use nunca com ideia de tempo, causa, motivo, dedução [...]" (MANUAL..., 2007, p.135).

$\mathrm{Na}$ gramática escolar de Cipro Neto e Infante, os autores enfatizam que "Quando pronome relativo, onde só pode ser usado na indicação de lugar, atuando sintaticamente como adjunto adverbial de lugar" e fazem uma longa explanação, ainda mais contundente. Inicia-se desta maneira: "Há uma forte tendência, na língua portuguesa atual, em usar onde como relativo universal, um verdadeiro 'cola-tudo"' (CIPRO NETO; INFANTE, 1999, p. 435-6). Chega, até mesmo, a 
atribuir tal uso à hipercorreção de falantes "de desempenho linguístico pouco eficiente" que tentam "falar difícil". E se os lembrássemos de que, de acordo com nossos especialistas em português arcaico, esse "uso cola-tudo" remonta ao século XIII? (MATTOS e SILVA apud LIMA, 2007, p.34).

Mais interessante ainda é a postura de Neves na sua "Gramática de usos do português", justamente por se tratar de uma obra descritiva. A autora não se mantém neutra quanto à questão, condenando: "O pronome relativo onde é muitas vezes empregado equivalendo a em que, mas sem valor locativo, o que não tem justificativa" (NEVES, 2000, p.386). No "Guia de usos do português" publicado três anos depois, ela se limita a dizer que tal uso é "condenado nas lições normativas", fornecendo ao leitor vários exemplos.

A maior surpresa é, de fato, a moderação do conservador Napoleão Almeida (diferentemente do que vimos na seção reservada a "o mesmo"). O gramático apresenta um exemplo de uso diverso, aqui transcrito: "Um artifício tão complicado quão praticamente inútil, de onde uma constituição positivista no Brasil republicano foi buscar o seu molde" (ALMEIDA, 2003, p.384). Logo em seguida, ainda afirma "Note-se que o antecedente não indica necessariamente lugar, sítio" (ALMEIDA, 2003, p.384).

Essa disparidade nas considerações sobre a adequação do uso não locativo de "onde" mostra que julgamentos desse tipo não encontram explicações consequentes na história interna da língua ou em análises lógicas de proposições, sendo permeados por motivações sóciohistóricas. Podemos dizer, em última instância, que o valor da forma linguística é decalcado do valor social do falante que a emprega, não sendo novamente possível separar a descrição das formas da língua de sua normatização. A questão que se coloca para o revisor de textos é como proceder em relação a usos contraditórios como esses, condenados e ao mesmo tempo possíveis, na análise de teóricos renomados e na prática de falantes cultos? Nossa reflexão não pretende propor uma resposta a este impasse, mas levar à consideração dos efeitos de uma tomada de posição, pois desejar que os discursos sobre a língua sejam apenas descritivos é sucumbir ao idealismo e exercer uma prática somente prescritiva é ignorar tanto a realidade da mudança quanto a produtividade da variação linguística, numa postura francamente dogmática. 


\section{Reflexões finais}

“... porque das coisas nascem as palavras, e não das palavras as coisas."

(Fernão de Oliveira)

A comparação entre estudos normativos e descritivos de expressões que causam polêmica entre gramáticos mais conservadores e linguistas mostra que a revisão das inadequações vocabulares não é tarefa banal. Revisores e autores precisam decidir em conjunto entre aceitar uma imagem social de cultivo e domínio da língua erudita ou assumir a postura mais inovadora de que a norma deve considerar o uso efetivo da língua e não ir contra ele. A complexidade dessa escolha deve fazer parte do cotidiano dos profissionais do texto para que eles possam construir seus argumentos de forma mais refletida e sem tantas idealizações a respeito do controle - muitas vezes inútil - que se busca exercer sobre a língua. A energia dispendida na correção obsessiva de formas linguísticas em processo de mudança pode ser comparada ao mito grego de Sísifo. Nesse caso, o revisor seria alguém que repete incessantemente a mesma tarefa de carregar morro acima uma pedra que, ao alcançar o cume, rola novamente montanha abaixo. Já os profissionais que buscam compreender o funcionamento da linguagem e da comunicação podem se dedicar a trabalhos menos impossíveis como compreender os sentidos do texto, refletir sobre suas ambiguidades e contradições, forjar uma argumentação mais adequada, investir na informatividade, na objetividade e na estruturação, dentre tantas outras funções. A ideia de que a língua tem uma relação íntima e complexa com o mundo, que ela parte do mundo e não o contrário, como afirma Fernão de Oliveira, pode contribuir para colocar em primeiro plano a tarefa primordial de qualquer linguagem: significar, comunicar, construir um mundo.

Segundo Benveniste (1989) a língua seria o interpretante por excelência da sociedade e o que lhe confere essa posição única e fundamental é sua função como instrumento de comunicação. A língua funciona então como uma máquina de produzir sentido. Sentido não apenas presente em designações que, como salienta o autor, conservam testemunhos riquíssimos sobre formas e fases da organização social, mas também em enunciações que, graças a mecanismos de transformação e expansão formais, colocam novos objetos linguísticos a circular no trajeto da comunicação, entendida de maneira ampla, etimológica, como colocação em comum. Então, quando o uso de determinadas expressões linguísticas mostra que novos sentidos e novas funções podem ser exercidos por velhas formas, certamente 
é um processo desse tipo que está em curso: a língua acontecendo nas práticas da comunicação humana.

Com relação às políticas linguísticas, podemos dizer que a possibilidade de municiar as línguas com escrita, manuais, gramáticas, dicionários, terminologias especializadas, sistemas de ensino e leis faz parte de práticas que intervêm num imaginário de língua, na língua que podemos descrever, instrumentar, revisar, controlar, comparar, padronizar. Mas a língua não é só objeto de ciência, normatização ou descrição, ela é também o meio pelo qual os homens se relacionam e constroem um mundo partilhado, ela tem uma ordem própria que se impõe aos falantes colocando limites e possibilidades ao dizer. É importante que se compreenda que as línguas resistem às interferências e normatizações não por vingança, mas pela complexidade de sua natureza (CALVET, 1996).

Em toda língua e em toda relação entre línguas e suas variantes atua, pois, uma política linguística específica que tenta organizar as práticas significativas e as forças sociais que estão em jogo. As chamadas intervenções in vivo, para usar a tipologia de Calvet (2002, p. 17), estão geralmente ligadas à intercompreensão na convivência entre línguas e a fenômenos identitários (como neologismos, gírias, jargões, socioletos, escolhas e proibições deliberadas de praticar um determinado idioma ou variante), sendo prova de que o uso é um motor importante de mudança na forma e na função das línguas. Já as intervenções in vitro, as políticas linguísticas propriamente ditas, das quais os profissionais do texto participam, gozam de maior legitimidade e alcance social, o que testemunha a importância das escolhas do revisor frente às controversas inadequações vocabulares.

Buscando outro olhar para o valor das línguas e suas variações, Calvet (1984, p. 64) diz que mais do que considerar a língua como instrumento de comunicação, podemos considerá-la antes como produto de uma necessidade de comunicação. Como resposta a um problema situado, a questão da comunicação passa a ser considerada não de forma apriorística, mas em seus desdobramentos práticos: diferentes tipos de necessidades projetam respostas diversas, o que coloca em primeiro plano o papel das relações socais (e suas disputas) na produção de demandas linguísticas.

Não se trata apenas de incluir o extralinguístico na reflexão sobre a língua. Tratase de considerar que a língua só pode ser pensada em sua dimensão política, que a forma, a função e o uso das línguas são fenômenos repletos de relações de poder. Essas relações criam, então, mais do que problemas de comunicação; elas criam desentendimento, isto é, uma "disputa sobre o que quer dizer falar". 
O desentendimento não é o conflito entre aquele que diz branco e aquele que diz preto. É o conflito entre aquele que diz branco e aquele que diz branco mas não entende a mesma coisa, ou não entende de modo nenhum que o outro diz a mesma coisa com o nome de brancura (RANCIÈRE, 1996, p.11).

Essa ideia de desentendimento coloca em questão o fato de que as formas linguísticas não estão desvinculadas do mundo, pois a língua constrói incessantemente os objetos dos quais fala, instaurando, assim, uma disputa pelos diversos enfoques possíveis em relação a eles. Além disso, como não há língua sem falantes, nem texto sem autor, o uso efetivo da linguagem instala também um litígio sobre a condição desigual entre aqueles que enunciam. Nas escolhas de editores e revisores, não pode, pois, haver consenso, apenas tensão, porque não se trata de optar por uma forma abstrata ou um conteúdo ideal, mas de determinar o peso que as construções linguísticas de determinados autores terão no espaço social.

\section{La pratique de révision de textes entre l'inadéquation et l'innovation: une réflexion sur variation, changement et politique linguistique}

\section{Résumé}

L'article discute les notions d'usage, variation et changement linguistique dans la pratique de révision textuelle par l'analyse de vocables polémiques parmi grammairiens traditionnels et linguistes. Ils sont condamnés par les conceptions plus puristes de la langue des emplois comme le démonstratif mesmo substantivé comme anaphorique et onde au sens non spatial, car ils ne seraient pas en accord avec un sens original défendu par les grammairiens. Les études linguistiques basées sur la description de l'usage de ces vocables montrent, toutefois, que ces nouvelles acceptions sont en pleine productivité dans la langue brésilienne, tel que le montrent les études sur la grammaticalisation dans le Portugais brésilien standard. Parmi ces deux positions, les professionnels du texte sont appelés dans sa pratique à décider sur la correction ou non des formes considérées à la foi comme inadéquates et innovantes. Le but de l'article est de contribuer à une 
décision plus réfléchie de ces professionnelles, en considérant le rôle de la révision textuelle dans les discutions sur les politiques linguistiques.

Mots-clés : Révision textuell. Inadéquations vocabulaires. Variation et changement linguistique. Grammaire d'usage. Politiques linguistiques.

\section{Referências}

ALMEIDA, Napoleão Mendes de. Dicionário de questões vernáculas. 4. ed. São Paulo: Ática, 2003.

BECHARA, Evanildo. Moderna gramática portuguesa. 37. ed. rev. e ampl. Rio de Janeiro: Lucerna, 2003.

BENVENISTE, Emile. (1968) Estrutura da língua e estrutura da sociedade. In: Problemas de linguística geral II. Campinas: Pontes, 1989, pp. 93-104.

BERNARDO, Sandra.Através denuma abordagem cognitiva. In:VASCONCELOS, Zinda de; AUGUSTO, Marina; SHEPHERD, Tania Granja. (Org.) Linguagem: teoria, análise e aplicações. Rio de Janeiro: Letra Capital, 2006. Disponível em: $<$ http://www.pgletras.uerj.br/linguistica/textos/livro03/LTAA03_prof005.pdf > Acesso em: ago. 2013.

BRASIL. Presidência da República. Manual de redação da Presidência da República. 2. ed. rev. e atual. Brasília: Presidência da República, 2002.

CALVET, Louis-Jean. Les politiques linguistiques. Col. Que sais-je?. Paris: PUF, 1996.

CALVET, Louis-Jean. Troc, marché et échange linguistique. Langage et société, n²7, 1984, pp. 55-81.Disponível em <http://www.persee.fr/web/revues/home/ prescript/article/lsoc_0181-4095_1984_num_27_1_1978>. Acesso em março de 2014.

CEGALlA, Domingos Paschoal. Dicionário de dificuldades da língua portuguesa. 3. ed. rev. e ampl. Rio de Janeiro: Lexikon, 2009.

CIPRO NETO, Pasquale; INFANTE, Ulisses. Gramática da língua portuguesa. São Paulo: Scipione, 1999.

CUNHA, Antônio Geraldo da. Dicionário etimológico da língua portuguesa. 4. ed. Rio de Janeiro: Lexikon, 2010.

FARACO, Carlos Alberto. Linguística histórica: uma introdução à história das línguas. São Paulo: Parábola, 2005. 
FERREIRA, Aurélio Buarque de Holanda. Novo Aurélio século XXI: o dicionário da língua portuguesa. 3. ed. Rio de Janeiro: Nova Fronteira, 1999.

GARCIA, Othon M. Comunicação em prosa moderna: aprenda a escrever, aprendendo a pensar. 27. ed. Rio de Janeiro: FGV, 2010.

GONÇALVES, Sebastião Carlos Leite; LIMA-HERNANDES, Maria Célia; CASSEB-GALVÃO, Vânia. (Org.). Introdução à gramaticalização: princípios teóricos \& aplicação. São Paulo: Parábola, 2007.

HOUAISS, Antônio. Dicionário Houaiss da língua portuguesa. Rio de Janeiro: Objetiva, 2007.

LAUSBERG, Heinrich. Linguística Românica. 2. ed. Lisboa: Fundação Calouste Gulbenkian, 1981.

LIMA, Sóstenes Cezar de. Impacto do vernáculo sobre o uso do ONDE na escrita monitorada. 2007. 141 f. Dissertação (Mestrado em Linguística) - Universidade de Brasília, 2007. Disponível em: <http://repositorio.unb.br/handle/10482/2913> . Acesso em: ago. 2013.

LUFT, Celso Pedro. ABC da língua culta. São Paulo: Globo, 2010.

MANUAL da redação: Folha de S. Paulo. 12. ed. São Paulo: Publifolha, 2007.

MARTINS FILHO, Plinio; ROLLEMBERG, Marcello. Edusp: um projeto editorial. 2. ed. São Paulo: Ateliê, 2001.

MARTINS, Eduardo (Org.). Manual de redação e estilo: O Estado de S. Paulo. 3. ed. São Paulo: O Estado de S. Paulo; Moderna, 1997.

NEVES, Maria Helena de Moura. Gramática de usos do português. São Paulo: UNESP, 2000.

NEVES, Maria Helena de Moura. Guia de uso do português: confrontando regras e usos. São Paulo: UNESP, 2003.

PERINI, Mário. Sofrendo a gramática. 3. ed. São Paulo: Ática, 2005.

QUEIROZ, Sônia (Org.). Editoração: arte e técnica. Belo Horizonte: FALE/ UFMG, 2008.

RANCIÈRE, Jacques. O desentendimento. São Paulo: Editora 34, 1996.

SILVA, Rosa Virgínia Mattos e. O português arcaico: morfologia e sintaxe. 2. ed. São Paulo: Contexto, 2001.

WEINREICH, Uriel; LABOV, William; HERZOG, Marvin. Fundamentos empíricos para uma teoria da mudança linguística. Trad. Marcos Bagno; 
revisão técnica Carlos Alberto Faraco. São Paulo: Parábola, 2006.

YAMAZAKI, Cristina. Editor de texto: quem é e o que faz. In: Congresso brasileiro de Ciências da Comunicação, XXX, 2007, Santos. Anais... São Paulo: Intercom, 2007.

YAMAZAKI, Cristina. Por uma edição de livros sem preconceitos. In: Colóquio Internacional de Comunicação para o desenvolvimento regional, XIII, 2008, Pelotas (RS). Anais... São Paulo: Intercom, 2008.

Submetido: 28/03/2016

Aceite: 08/07/2016 